\title{
Guest Editorial: The Future is Feminist
}

\author{
Rochelle Jones $^{1,2}$
}

Published online: 20 November 2017

(C) Society for International Development 2017

AWID's 13th International Forum on Women's Rights and Development was held 8-11 September 2016 in Bahia, Brazil, with the theme 'Feminist Futures: Building Collective Power for Rights and Justice'. ${ }^{1}$ So much more than events or conferences, AWID Forums are multidimensional. They are deeply collaborative processes-often years in the making. And they do not end when everybody goes 'home'. There's something so 'gemütlich'2 and yet energizing about sharing a space with close to 2000 other activists - mostly women - bent on resisting oppression in all its manifestations. More than this however, the AWID Forum processes offer a rare opportunity for the full spectrum of interaction and engagement-virtual, face to face, cerebral, emotional and even visceral. They represent a unique blend of structure and unstructure-tending towards the 'unconference' with power operating in a more fluid and contingent way. They are a coming together of people, ideas and visions, and like the mixing of different chemical substances they create something new in the end. Most importantly, AWID Forums aspire to be safe feminist spaces striving to better understand privilege and hence eradicate oppression. Convening representatives from multiple movements means that participants commit to the Forum's values: Diversity; Human Rights; Autonomy; Cooperation; and Responsibility. It is the atmosphere of mutual feminist respect and solidarity that makes AWID Forums so unique. Afterall, building feminist futures begins with how we treat each other.

\section{Rochelle Jones}

1 Association for Women's Rights in Development (AWID), Brisbane, Australia

212 Raven Street, West End, QLD 4101, Australia
When looked at en masse, AWID Forum participants present a very disunited front. Yet underneath the seemingly miscellaneous cacophony of language, dress, colour and culture, all are walking interconnected pathways-intent on disrupting and designing their way to better, happier, healthier, more holistic times. As Miriam Miranda from Honduras stated in the Opening Plenary, this was a room full of people who are doing their very best to 'prevent the collective suicide humanity is facing'.

It is difficult to prepare for an AWID Forum. If you have participated in one before, then you'll be familiar with the wave of passion, anger, sadness, inspiration and intellectual joy that seems to cascade over you again and again. You will be familiar with the emotion-simmering gently around your collarbone most of the time, but then escalating to a rapid boil quite suddenly-forcing you to swallow and mitigate potential volcanic outbursts. If you have not participated in an AWID Forum before, then I can only encourage you to start organizing for the next one, because they get better and better every time, and they produce so much inspiring feminist output in such a short

\footnotetext{
${ }^{1}$ See the Forum website for detailed programme information, news and resources: http://www.forum.awid.org/forum16/. AWID's Board of Directors decided to organize the 2016 Forum in Brazil for many reasons. Geographically, it was a logical step given that previous Forums were in Mexico (2002), Thailand (2005), South Africa (2008) and Turkey (2012) — so moving the Forum back to Latin America, and particularly South America made sense. Politically, at the time the decision was made, Brazil's growing role in the global scene and its experiments with a range of programmes to address inequality also made it a very interesting location for a Forum. And perhaps most importantly, the long history of social movement organizing in Brazil strongly resonated with our Forum theme, and the emphasis on crossmovement engagement to face the complexities in Brazil's context, especially as the political situation became increasingly uncertain, mirrored what is happening all around the world.

${ }^{2}$ A state or feeling of warmth, coziness.
} 
period of time it makes your head spin. I say this, admittedly, as a staff member of AWID, but these assurances and praises come from a place of light and love, not from any rigid, obligatory space.

This was my third Forum experience, and the 2016 Forum had some inspiring differences. In the year leading up to the Forum, AWID and the Forum International Planning Committee (IPC) were very deliberate about putting systems and resources in place to ensure the meaningful participation of a range of movements outside of the 'usual suspects' of women's rights organizing-including environment, labour and peace, but in particular movements in the 'periphery': women with disabilities; Black and Afro-descendant women; sex workers; Indigenous women; Trans* and intersex activists; and domestic workers. The convening of the Black Feminisms Forum ${ }^{3}$ in Bahia, for example, was an historic first-created by Black feminists for Black feminists.

The result of this engagement was extraordinary-with diverse experiences of (in)justice centring and framing the whole Forum process. What we co-created in the end was a much-needed (and widely appreciated) space for movements to come together, explore visions for the future and strategize for working together more effectively. Indeed, we learned that we are incredible together, and that by joining hands across our boundaries, we can better articulate both what we are for and what we are against in order to envision and work towards better-feminist-futures. We also learned that as a response to the asymmetrical power maintaining the categories and norms of our social, political and even personal lives at almost any cost, feminist activists are adapting, operating less and less within the institutions and systems that characterize the 'modern' world, and co-creating our own feminist villages, categories and identities, using dissent and the spaces of exclusion and 'abnormality' as our foundation. Paying heed to the Forum experience, we have put together in this issue a diverse line-up of activists, artists and academics who participated in the Forum, providing some insight into the challenging contexts we face, and the groundswell of rich feminist knowledge and praxis being used to push back and co-create alternative realities.

\footnotetext{
3 Bahia, Brazil is a region of significance in Black freedom movements, so Black feminists seized the moment to create a historic global gathering of over 200 hundred Black feminists over 2 days just before the AWID Forum. See: http://www.forum.awid.org/forum16/ program/black-feminisms-forum-bff.
}

\section{Why 'Feminist Futures'?}

The 2016 Forum's theme emerged from the urgency of the moment. Looking across the vast landscape of our interconnected experiences, we see deepening inequality and poverty, the rise of fundamentalisms, destruction of the Earth as well as increasing division and conflict. What we see also is that you cannot fight fire with fire. The neoliberal paradigm of privatization and growth has largely failed the majority, and so too has the 'development' paradigmthe hitherto answer to the ongoing problems of neoliberalism. Laissez-faire corporate regulation and capitalism as answers to poverty and inequality fail to see their own footsteps in the problems they are purporting to solve. And as more and more people stand up to defend rights and the Earth against these ailing institutions, systems and norms, the response has been denial, violence and repression. Particularly women, women's bodies and women's rights are used to delineate the borders of power. But as Awino Okech highlights in her article in the Upfront section, 'Black, brown, Muslim, queer, gender non-conforming, differently abled bodies across the world are under threat'. Those who are categorized as 'other'. Those who have been placed in spaces of exclusion and abnormality are being used to 'symbolically defin(e) the limits of national difference and power'.

We are facing a widespread shrinking of democratic space and the criminalization of social dissent and activism. This was a major undercurrent throughout the Forum. The durability and strength of democratic systems is being questioned and hard-won rights are being curbed or withdrawn, superintended by patriarchal, neoliberal, religious, colonial and fascist agendas. Certainly, the impeachment of Dilma Rousseff in Brazil, replacing a democratically elected Head of State with an alignment of conservatives, predominately white and male, is an example, and in the Upfront section Lydia Alpizar and Jurema Werneck discuss how the complex and polarized political landscape in the Forum's host country mirrors global trends that many of us are experiencing in different parts of the world. During a 3-h session at the Forum, participants from all around the world discussed how civic space is being restricted and, in the Thematic section, Semanur Karaman brings the threads of this discussion together, noting that States are not acting alone-but are often backed by conservative and fundamentalist ideologies and interests. In the USA, we witnessed Donald Trump rise to power and begin a concerted attack on various freedoms and liberties-one example being the reinstatement of the global gag rule on abortion (Terkel 2017); and in Russia, under Vladimir Putin, the law was changed to decriminalize domestic violence (Walker 2017). As Fareen Walji explains in her article, these 
restrictions are having a particularly severe impact on funding, as States introduce restrictions on foreign funding as a means of cutting off resources required to sustain independent civil society operations.

While feminist and other progressive social movements have long been organizing to resist, withstand, respond to and disrupt the various challenges and trends we have faced over time, the urgency of this moment compels us to emerge from our silos and find ways to better work at the intersections of our activism to build stronger and bigger movements, to learn from each other and to co-create the futures we want. These complex issues require us to work together in a dialectic. They also require communities of care to sustain us-as elucidated in Inna Michaeli's piece.

\section{Why the AWID Forum Matters}

By bringing together so many diverse movements and focusing the lens on interconnected justice struggles, that is, the deep impacts of colonialism, capitalism, racism and gendered binaries - there was a shift to a more Global, less White/Northern 'face' of feminism-flipping the questions of power, voice and space. There was a nurturing of the spaces of exclusion and 'abnormality' where resistance is born. We have tried to reflect this in the articles of this issue-particularly in the Dialogue section, which features diverse views and thoughts by constituencies and social groups that are too often left in the margins of the debate. Young feminist activists, women with disabilities, Black and Afro-descendant women, Trans* activists and sex workers were celebrated as key organizing partners.

I would like to highlight two key threads among the several that emerged from the AWID Forum. Firstly, our diversity led us to an (ongoing) interrogation of solidarity and the importance of feminism as both a safe space to retreat to in a world rife with division and oppression, and a space where we can visualize, imagine and co-create together. There were activists from all corners of the globe present in Bahia-some that are unable to speak up in their own contexts for fear of being targeted. The Forum gave participants a safe space to share stories and strategies and learn they are not alone. More than this, many participants indicated they were encouraged to move outside their comfort zones and engage with movements and issues that are different to and maybe even in conflict with their own. Participants were also moved to visualize what a feminist future might actually look like. What do we want? What will it take? Who will it take? How will it be done? For example, the Plenary on day three was facilitated by the Fearless Collective - a group of three young, visionary activists who guided us through an imaginative and emotionally resonant process that highlighted the importance of visioning and suspending our disbeliefs. Their article 'Fearless Futures' and inspiring artwork in the Thematic Section captures the importance of this under-utilized methodology brilliantly. Many left the Forum inspired to 'start living our future today'. That is, participants took away an urgency for building their work from the collective vision of what we want, and not just a focus on holding the line. The positive, aspirational emphasis was an important antidote to the dire contexts that so many of us are facing.

The second thread was the recognition that we cannot rely on the current systems anymore to make change happen. We are coming together in solidarity across the world to imagine and co-create our own futures free from oppression, and a big part of this is a reduced reliance on the state and other borders. The AWID Forum was like a microcosm of the borderless, feminist villages we dared to imagine. And while the crises confronting us and our planet are in so many ways borderless and interconnected, these crises demand a borderless, transversal activism in response-bringing us together beyond our own boundaries of issues, sectors, locations and identities. Roland Bleiker defines the term 'transversal dissent' as 'a political practice that not only transgresses national boundaries, but also questions the spatial logic through which these boundaries have come to constitute and frame the conduct of international relations' (2000: 2). Moving away from fundamental levels of analysis such as the system, the state or the individual, Bleiker's analysis of domination and dissent encapsulates the way that political, social and economic life today is transversal-that is, it transgresses boundaries and intersects at multiple sites, creating more of a complex web of subjectivities rather than neat categories that can be measured objectively.

Our diverse movements are becoming powerful interconnected webs of transversal dissent, vision and action that circumvent the state. For example, there are the strengthening alliances between Black, Indigenous and grassroots movements coming together around climate change and including gender, race and class analysis in their demands, and greater transnational solidarity between, for example, \#BlackLivesMatter and other struggles-from Ferguson to Palestine and Brazil, plus Dalit struggles and Indigenous actions. In this issue, young feminist Dilar Dirik's analysis of the Kurdish Women's Movement discusses Democratic Confederalism, which aims at creating autonomous, grassroots democratic structures in the form of a stateless, radical democracy. Another less acknowledged example is the increasing visibility and role of art and artivism to move us emotionally and to challenge and disrupt social and cultural norms around the world. Art has no borders. At the Forum, like in our larger realities, art was woven into the fabric to confront, soothe 
and stimulate our hearts, minds and souls. Monica Enriquez, Vanina Serra and Ruby Johnson, who co-organized the Artivism space at the Forum, write about the importance of funding art as activism in the Local/Global Encounters section.

There are already innovative strategies being employed by various movements and alliances to achieve our grand designs, many of them discussed at the Forum. We should remind ourselves that the increasing inequality, insecurity, poverty, division and violence we face has also resulted in a greater popularization and theorizing of alternative, more peaceful realities that are less destructive to our bodies and planet. We should not forget that the worldwide backlash on women's rights is because women continue to rise. A great benefit of our more interconnected world is that more people are aware of injustice and are rising up against it using diverse and transverse methods. The worldwide refugee crisis is one example, climate change another. The Local/Global Encounters section provides a small sample of cross-movement, cross-border strategies that were shared and discussed at the Forum and demonstrates how we are coming together-such as the development of a Roma/First Nations/Dalit coalition, as described by Kerieva McCormick; Naureen Shameem's article on the Observatory on Universality of Rights collaborative initiative to counter the attacks by anti-rights actors on the international human rights framework; and, Geetanjali Misra and Nafisa Ferdous' analysis of what works and what does not in the fight for decriminalization of sexuality in India.

I find it important also to mention what could not be included in this issue. It was impossible to represent here all the movements, issues and strategies that were present at the Forum. There were close to 200 participant-led sessions being run over 4 days, five plenaries, four umbrella sessions and cross-movement initiatives. There were caucuses, art exhibitions, film screenings and the Women Human Rights Defenders Tribute to honour those who are no longer with us. There was the Young Feminist Activist Hub; the Feminist Internet Exchange and the Feminist Resource Mobilization Hub with its 'Donor Office Hours' to promote open dialogue between funders and activists. And at the Sustaining Our Activism WHRD Hub, participants could learn about feminist approaches to holistic security and self-care.

To conclude, I want to reflect a little on solidarity and how we move forward and out of our silos. How we respond to the world and its squabbling reminds me of the sculpture The Spirit of Haida Gwaii, by Bill Reid. Having only ever seen the sculpture in pictures, I will quote Tully (1995), who used the Spirit of Haida Gwaii to inform his work on constitutional recognition in multicultural societies:

The sculpture is a black bronze canoe, over nineteen feet in length, eleven feet wide, and twelve feet high, containing thirteen passengers, sghaana (spirits or myth creatures) from Haida mythology (Tully 1995: 17).

Haida Gwaii is an archipelago in British Columbia, Canada-formerly the Queen Charlotte Islands-off the northwest coast of North America. The Haida nation was reduced of $90 \%$, from ten thousand indigenous occupants to just 558, over a period of 138 years of European occupation. Tully describes Bill Reid's sculpture as a symbol of the 'wide variety of complex and interrelated societies' (Tully 1995: 19) that lived in the Americas before European settlement and asks us to imagine The Spirit of Haida Gwaii as a constitutional dialogue (1995: 24) of mutual recognition. In the spirit of creative visioning, and using the following imaginary of the Spirit of Haida Gwaii that I borrow from Tully, I ask you to reflect on our diversity, and our feminist dialectic, as we move forward with oars poised:

The passengers are squabbling and vying for recognition and position each in their culturally distinct way. They are exchanging their diverse stories and claims... without imposing a meta-language or allowing any speaker to set the terms of the discussion... The narratives of the thirteen voyageurs tell of how their identities have been shaped and formed through millennia of overlapping interaction together. They exist as they are, in all their distinctiveness, not in spite of, but in virtue of, their interdependency over time and history. (Tully 1995: 24-25).

\section{References}

Bleiker, Roland. 2000. Popular Dissent, Human Agency and Global Politics. Cambridge: Cambridge University Press.

Terkel, Amanda. 2017. Donald Trump Reinstates Ronald Reagan's Abortion 'Global Gag Rule'. The Huffington Post. 24 January 2017. http://www.huffingtonpost.com.au/2017/01/23/donaldtrump-reinstates-ronald-reagans-abortion-global-gag-rul/?utm_ hp_ref=au-homepage. Accessed 26 Jan 2017.

Tully, James. 1995. Strange Multiplicity: Constitutionalism and Diversity. Cambridge: Cambridge University Press.

Walker, Shaun. 2017. Putin Approves Legal Change that Decriminalises Some Domestic Violence. The Guardian. 8 February 2017. https://www.theguardian.com/world/2017/feb/07/putinapproves-change-to-law-decriminalising-domestic-violence. Accessed 31 Oct 2017. 